\title{
INTERNATIONAL
}

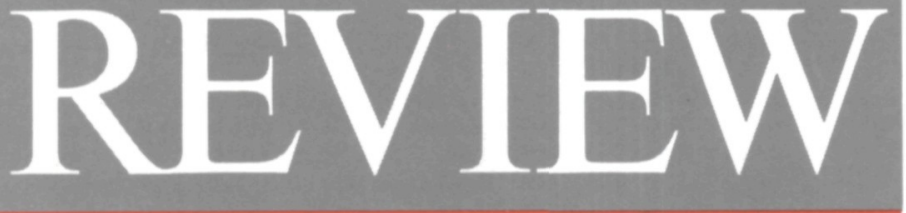

\section{OF THE RED CROSS}
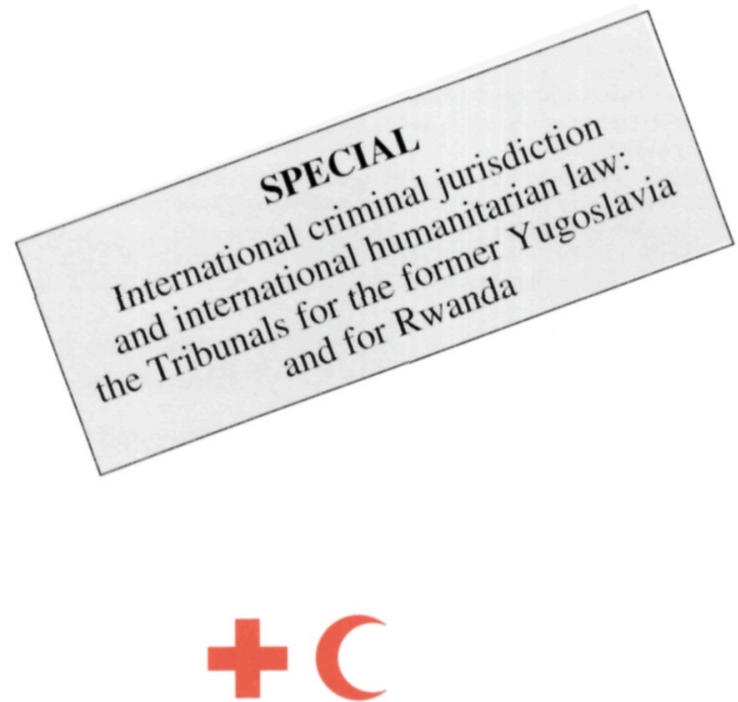

Published every two months by the International Committee of the Red Cross for the International Red Cross and Red Crescent Movement

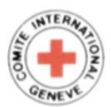




\section{INTERNATIONAL COMMITTEE OF THE RED CROSS}

CORNELIO SOMMARUGA, Doctor of Laws of the University of Zurich. Doctor h.c. of Fribourg University (Switzerland), Minho University, Braga (Portugal), Bologna University (Italy). Nice-Sophia Antipolis University (France), Seoul National University (Republic of Korea) and Geneva University, President (member since 1986)

PIERRE KELLER, Doctor of Philosophy in International Relations (Yale), banker, Vice-President (1984)

ERIC ROETHLISBERGER, Doctorate of Political Science from the Graduate Institute of International Studie. in Geneva, permanent Vice-President (1994)

ULRICH GAUDENZ MIDDENDORP, Doctor of Medicine, lecturer at the Faculty of Medicine. University of Zurich, former head of the surgical department of the Cantonal Hospital. Winterthur (1973)

RENÉE GUISAN, General Secretary of the Institut de la Vie international, head of medico-social institutions in the Canton of Vaud, member of the International Association for Volunteer Fffort (1986)

ANNE PETITPIERRE, Doctor of Laws. Barrister, Professor at the Law Faculty of the University of Geneva (1987)

PAOLO BERNASCONI, Barrister, Bachelor of Laws, lecturer in fiscal law and economic criminal law at the Universities of St. Gallen. Zurich and Milan (Bocconi), former Public Prosecutor at Lugano (1987)

LISELOTTE KRAUS-GURNY, Doctor of Laws of the University of Zurich (1988)

SUSY BRUSCHWELLER, nurse, former Director of the Swiss Red Cross College of Nuring in Aarat. Chairwoman, SV-Service, Contract Catering (1988)

JACQUES FORSTER, Doctor of Economics, Professor at the Graduate Institute of Development Studies in Geneva (1988)

JACQUES MOREILLON, Bachelor of Laws, Doctor of Political Science, Secretary General of the World Organization of the Scout Movement, former Director General at the ICRC (1988)

MAX DAETWYLER, graduate in Economics and Social Sciences of the University of Genevi. Scholar in Residence of the International Management Institute (IMI) of Geneva (1989)

RODOLPHE DE HALLER, Doctor of Medicine, lecturer at the Faculty of Medicine of the University of Geneva, former President of the Swiss Association Against Tuberculosis and Lung Discases (1991)

DANIEL THURER, Doctor of Laws, LL. M. (Cambridge), Profestor at the University of Zurich (1991)

JEAN-FRANÇOIS AUBERT, Doctor of Laws, Professor at the University of Neuchâtel, former member of the Swiss National Council and Council of States (1993)

JOSEF FELDMANN, Ph.D., lecturer at the University of St. Gallen, Corps Commander (Rtd.) of the Swis: army (1993)

GEORGES-ANDRE CUENDET, Bachelor of Laws of the University of Gencva, graduate of the Institute of Political Studies of the University of Paris, Master of Arts of Stanford University (USA), member of the Administrative Council of Cologny, Geneva (1993)

ERNST A. BRUGGER, Doctor of Natural Science, consultant for economic development issues, professor at the University of Zurich (1995)

JEAN-ROGER BONVIN, Doctor of Economics of the University of St Gallen. President of the Development Centre of the Organisation for Economic Co-operation and Development (OECD). Paris ( 1996)

JAKOB NÜESCH, agricultural engineering and doctorate in technical sciences from the Federal Institute of Technology in Zurich, Professor of Microbiology at the University of Basle. former President of the Federal Institute of Technology in Zurich (1997)

\section{EXECUTIVE BOARD}

Cornelio Sommaruga, President

Eric ROETHILISHFRGER, permanent Vice-Prevident

Jacques Forstik, member of the ICRC

Anne Petitrierre, member of the $/ C R C$
Jean De: Colleten. Director of Operations Yves SANDo7, Director for Intermational Law and Polic)

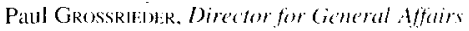

The International Committee of the Red Cross (ICRC) and the International Federation of Red Cross and Red Crescent Societies, together with the National Red Cross and Red Crescent Societies, form the International Red Cross and Red Crescent Movement.

The $I C R C$, which gave rise to the Movement, is an independent humanitarian institution. As a neutral intermediary in the event of armed conflict or unrest it endeavours, on its own initiative or on the basis of the Geneva Conventions, 10 bring protection and assistance to the victims of international and non-international armed conflict and internal disturbances and tension. 


\section{INTERNATIONAL REVIEW OF THE RED CROSS}

No. 321

November-December 1997

International criminal jurisdiction and international humanitarian law: the Tribunals for the former Yugoslavia and for Rwanda

Foreword by Judge Antonio Cassese, former President of the International Criminal Tribunal for the former Yugoslavia

Foreword by Judge Laïty Kama, President of the International Criminal Tribunal for Rwanda

The experience of the International Criminal Tribunals for the former Yugoslavia and for Rwanda

Palul Tavemier

International criminal jurisdiction, international humanitarian law and humanitarian action

Jacques Stroun

A tremendous challenge for the International Criminal Tribunals: reconciling the requirements of international humanitarian law with those of fair trial

Anne-Marie La Rosa 
Jurisdiction of the ad hoc Tribunals for the former Yugoslavia and Rwanda over crimes against humanity and genocide

Marie-Claude Roberge

The Rwanda Tribunal: its role in the African context

The Rwanda Tribunal : a presentation of some legal aspects

Frederik Harhoff ....

The International Criminal Tribunal for Rwanda

Cécile Aptel

The International Criminal Tribunal for Rwanda

Its role in the African context

Djiena Wembou

The International Criminal Tribunal for Rwanda: bringing the killers to book

Chris Maina Peter.

The International Criminal Tribunal for Rwanda

Are all issues addressed? How does it compare to South Africa's Truth and Reconciliation Commission?

Gerhard Erasmus and Nadine Fourie

Rwanda's national criminal courts and the International Tribunal Olivier Dubois

\section{In the Red Cross and Red Crescent world}

Recognition of the Kiribati Red Cross Society ............................. 733

Recognition of the Palau Red Cross Society ..................................... 733

Recognition of the Tajikistan Red Crescent Society ........................ 733

Recognition of the Georgia Red Cross Society ............................... 7333

\section{Books and Reviews}

Zhu Wen-Qi, Outline of international humanitarian law

Sienho Yee

Économie des guerres civiles, edited by François Jean and Jean-Christophe Rufin

François Grunewald. 
Simone Delorenzi, Face aux impasses de l'action humanitaire internationale: la politique du CICR depuis la fin de la guerre froide Véronique Harouel.

Media and humanitarian endeavour

Kim Gordon-Bates...

\section{Miscellaneous}

CD-ROM on International Humanitarian Law

The Paul Reuter Fund

Postgraduate degree in humanitarian action - University of Geneva 763

Contents 1997

\section{Announcement}

From 1998 the International Review of the Red Cross will be published quarterly instead of every two months. This decision has been taken as a cost-cutting measure. The editors will endeavour to make the Review even more interesting by offering a rich and varied selection of items and contributions by a wide range of authors.

We trust that the Review will continue to attract the same loyal readership.

International Committee of the Red Cross 